\title{
EMISSION AND ATMOSPHERIC IMPACT OF A CUBAN REFINERY
}

\author{
J. A. Colás, | ABSTRACT \\ M. Díaz, \\ O. Álvarez, \\ and R. Teuteló \\ In the processes of an oil refinery, considerable emissions of atmospheric pollutants are \\ generated that produces hazard to man's health and the environment. In this study, the \\ obtained results of the characterization of the gaseous emissions by chimneys of the furnaces \\ and boilers of the refinery are presented. The sampling and analysis of $\mathrm{SO}_{2}, \mathrm{NO}_{\mathrm{x}}, \mathrm{CO}$, \\ total suspended particles, and flow measurements were carried out. The aromatic \\ hydrocarbons were determined by UV Spectroscopy. The model of dispersion of pollutants \\ emitted by chimneys was executed using the software for the calculation of the gas \\ concentration from continuous industrial sources following the methodology approved in \\ the Cuban standards, according to the Berliand Model. We conclude that the combustion \\ processes of the Refinery reflect a fault, given the particles emissions. The emissions of \\ the furnaces and boilers exert negative impact or pressure on the atmospheric environment \\ in the area. \\ Keywords: refinery, impact, heaters, boilers
}

\section{NOMENCLATURE}

$\begin{array}{ll}\mathrm{A} & \text { atmospheric thermal stratification constant } \\ \mathrm{C}_{20 \mathrm{~min}} & \text { instantaneous concentration, } \mathrm{mg} / \mathrm{m}^{3} \\ \mathrm{C}_{24 \mathrm{~h}} & \text { daily average concentration, } \mathrm{mg} / \mathrm{m}^{3} \\ \mathrm{CO} & \text { carbon monoxide } \\ \mathrm{D} & \text { stack diameter, } \mathrm{m} \\ \mathrm{Dist} & \text { distance, } \mathrm{m} \\ \mathrm{E} & \text { gases emission, } \mathrm{g} / \mathrm{s} \\ \mathrm{GF} & \text { glass fiber } \\ \mathrm{H} & \text { stack height, } \mathrm{m} \\ \mathrm{HCA} & \text { aromatic hydrocarbons } \\ \mathrm{NOx} & \text { nitrogen oxides } \\ \mathrm{RC} & \text { concentration ratio } \\ \mathrm{SO} & \text { sulfur dioxide } \\ \mathrm{T} & \text { stack gases temperature, }{ }^{\circ} \mathrm{C} \\ \mathrm{TSP} & \text { total suspended particles } \\ \mathrm{V} & \text { stack gases velocity, } \mathrm{m} / \mathrm{s} \\ \text { VOC } & \text { volatile organic compounds }\end{array}$

\section{Greek symbols}

$\alpha \quad$ confidence level

\section{INTRODUCTION}

The correct evaluation of the atmospheric environment to know the levels of pollutants in the oil activity is one of the fundamental demands for the taking of measures that guarantee to maintain the appropriate levels with relationship to the quality of the environment (Slater, 1996).

The nitrogen oxides (NOx) are chemical compounds, in their largest part derived from combustion processes, product of the contained nitrogen in the air that is required for the combustion. There also exist natural sources, mainly for the bacterial activity in the soil.

The so called acid rain is a different form of air pollution originated by wet deposition of sulfur and nitrogen oxides that has been studied a lot in recent years (UNEP, 1992; López, 1995).

The total suspended particles (TSP) that originate from the incomplete combustion of carbon (soot) increase the existent breathing and cardiovascular illnesses, they alter the organic defense systems, damage lung tissues and can cause cancer and premature death (Porteous, 1996). People with flu, asthma or lung or cardiovascular illnesses are the most vulnerable, along with the children and the elderly.

The volatile organic compounds (VOC) can cause great number of noxious goods for the health, being cancer one of the worries, since it is not established a clear threshold of exposure. The cancer, is assumed to take place when a simple cell, due to changes in its DNA, spreads by multiplying without control and at great speed. It has been demonstrated that very small concentrations of VOC can attack the DNA. The affected cell can increase its speed of duplication in a non controlled way until reaching a high concentration of cells that is recognized as a cancer (Wagner, 1996). 
The carbon monoxide (CO) is the most abundant and broadly distributed atmospheric pollutant of those that are in the inferior layer. It is present in the flue gases of vehicles and in effluents for incomplete combustion.

The short and long term monitoring of emissions is of great importance to determine if the oil activity in a certain area is causing contamination. The effective programs of monitoring can identify the problems before they become a threat to the environment (Kiely, 1997).

One of the factors to keep in mind in the sampling of gases is the heterogeneity of the discharge in the duct, which is manifested in the distribution of speeds (Yoest and Fitzgerald, 1996).

For the sampling of gases three main methods have been broadly utilized: scrubbing, condensation to low temperature and adsorption (Cheremisinoff and Morresi, 1978; Calvert and Englund, 1984; Yoest and Fitzgerald, 1996; Brieda et al., 1986; Rudolph et al., 1997).

The recently developed equipments for the sampling and automatic determination of concentrations of gases in stationary sources (ISO 10396, 1993; Jahnke, 1993) include some of these basic methods, although their recommended locations are in places with easy access and they are affected by high concentrations of particles (Novello, 1995; White, 1995).

The sampling of particles under isokinetic conditions has to guarantee representative samples of each emission, avoiding inertial forces that become more significant for the particles bigger than three microns. The well-known methodologies are applied using a system that inserts a filter paper to pick up the particles. Filters of glass fiber type GF/A and filters FPP-15 are used. The samples take in the same points of measurement of speed, picking up samples integrated in the time, applying the concept of accommodation of temporary and spatial variations before referred.

For the calculation of the dispersion of pollutants in the atmosphere three fundamental theoretical systems exist, with multiple numeric solutions, for their practical use in the establishment of the environmental impact of emissions of stationary sources.

Starting from the basic formulas of Berliand, different methodologies of calculation of dispersion of pollutants were developed, finding wide acceptance and application in Eastern Europe and Cuba, where it has been adopted as standard methodology (NC 39, 1999) using a value of 200 for the constant of atmospheric thermal stratification (A) according to that proposed for our environmental conditions (López, 1984).

\section{EXPERIMENTS}

The gaseous emissions of stationary sources of the boilers and ovens of a Cuban refinery of petroleum were characterized, by flow measurement and sampling program according to established methodologies (Yoest and Fitzgerald, 1996; ARPEL, 1998; ARPEL, 1997).

The sampling of $\mathrm{SO}_{2}, \mathrm{NO}_{\mathrm{X}}, \mathrm{CO}, \mathrm{CO}_{2}$ and $\mathrm{O}_{2}$, were executed with a Combustion Analyzer, MSI model from Draeger. The sampling of total suspended particles in chimneys was carried out isokinetically by its collection in a filter for its analysis for the gravimetric method (ISO 9096, 1992). Measurements of flow by means of a Pitot type $\mathrm{S}$ tube were also carried out.

The sampling to determine aromatic hydrocarbons was carried out on activated carbon with later elution with $n$-hexane for its analysis for Ultraviolet spectroscopy in a spectrophotometer Cintra 40 of the GBC, using n-hexane bi distilled like reference. The concentration was calculated by means of a calibration curve prepared with an international standard. The absorbances were obtained to $255 \mathrm{~nm}$ with quartz cuvette of $1 \mathrm{~cm}$ of light path, slit of $1.5 \mathrm{~nm}$ and time of integration of 1 second. The spectra were obtained in the same equipment in the range of $200-400 \mathrm{~nm}$, interval of data of $0.853 \mathrm{~nm}$, slit of $1.5 \mathrm{~nm}$ and speed of registration of $1000 \mathrm{~nm} / \mathrm{s}$.

The model of dispersion of pollutants emitted by chimneys was executed using the program for the calculation of the concentration starting from continuous industrial sources (Álvarez, 1994) following the methodology approved in the Cuban norm (NC 39: 1999) according to the pattern of Berliand. The value of the constant of atmospheric thermal stratification A that it defines the most adverse natural conditions of diffusion took similar to 200, according to that proposed for our country for flat areas or with topography of little complexity and height, which has been accepted in the Cuban norm of reference. The meteorological data were taken from the Climatic Summary of Cuba (1991), published by INSMET.

The model of the dispersion was carried out 


\section{TECNOLOGIA/TECHNOLOGY}

for the $\mathrm{SO}_{2}$ that is the fundamental pollutant emitted by the valued sources. The data of the emissions of ovens and boilers (Tab. 1) for the dispersion calculations were obtained in the own emission sources, giving higher validity to the survey.

Table 1. Data of emissions for calculations of dispersion of pollutants.

\begin{tabular}{|c|c|c|c|c|c|c|c|}
\hline \multicolumn{2}{|c|}{ Chimneys } & $\begin{array}{c}\mathrm{v} \\
(\mathrm{m} / \mathrm{s})\end{array}$ & $\begin{array}{c}\mathrm{D} \\
(\mathrm{m})\end{array}$ & $\begin{array}{c}\mathrm{H} \\
(\mathrm{m})\end{array}$ & $\begin{array}{c}\mathrm{T} g \\
\left({ }^{\circ} \mathrm{C}\right)\end{array}$ & $\begin{array}{c}\mathrm{E} \\
(\mathrm{g} / \mathrm{s})\end{array}$ & $\begin{array}{c}\Delta \mathrm{T} \\
\left({ }^{\circ} \mathrm{C}\right)\end{array}$ \\
\hline \multirow{3}{*}{ Ovens } & $\mathrm{F} 101$ & & & & & & \\
& $\mathrm{~F} 102$ & 1.20 & 3.00 & 55 & 590 & 42.6 & 547 \\
& $\mathrm{~F} 103$ & & & & & & \\
\hline \multirow{3}{*}{ Boilers } & 1 & 3 & 1.20 & 8.36 & 363 & 7.2 & 320 \\
\cline { 2 - 9 } & 2 & 3 & 1.20 & 8.36 & 363 & 7.2 & 320 \\
\cline { 2 - 9 } & 3 & 3 & 1.20 & 8.36 & 363 & 7.2 & 320 \\
\hline
\end{tabular}

In the cartography it was considered the annual average frequency of occurrence of the mean values of speed for each one of the 16 directions of the wind (Álvarez, 1994), taking the meteorological data that appears in the Climatic Summary of Cuba (1991).

For the development of this work the digital sheets of Cuba were used (sheet 1: 250 000), made for the Geographical Information System INFOPET (1999) of the Petroleum research Center (CEINPET). The geodesic data were converted to the Lambert North Coordinated System.

The data of the relative concentration of the $\mathrm{SO}_{2}$ were interpolated using the system Surfer 7 for Windows starting from the results of the program of calculation of the dispersion, using as interpolation method a liner krigging, adding it to the cartographic representation of the area.

In the statistical prosecution of data the program STATISTICA was used to determine behavior averages and correlations of interest.

\section{RESULTS AND DISCUSSION}

As it is observed in Tab. 2, the level of concentration of sulfur dioxide in the ovens and the boilers are about three times higher than the limits that should not be exceeded of pollutants emitted by chimneys for these processes (World Bank Group, 1997), as a result of the use of crude oil with high sulfur content (ARPEL, 1992). In the ovens, the levels of $\mathrm{NO}_{\mathrm{X}}$, as the suspended particles are inside that regulated. The Aromatic Hydrocarbons are not regulated in these norms, although the opposing levels are considered high, keeping in mind their adverse effects to human health. In the boilers the concentrations of PST are superior to the limits before referred, and it also reflects a faulty combustion (ARPEL, 1999). The $\mathrm{NO}_{\mathrm{X}}$ content is within the regulation.

It can be seen in Tab. 3 that the emitted load of $\mathrm{SO}_{2}$ for the ovens and boilers are significant.

Table 2. Characterization of emissions originated in chimneys of Refinerya .

\begin{tabular}{|c|c|c|c|c|c|}
\hline Chimneys $^{\mathrm{a}}$ & $\begin{array}{c}\mathrm{SO}_{2} \\
\left(\mathrm{mg} / \mathrm{m}^{3}\right)\end{array}$ & $\begin{array}{c}\mathrm{NO}_{\mathrm{X}} \\
\left(\mathrm{mg} / \mathrm{m}^{3}\right)\end{array}$ & $\begin{array}{c}\mathrm{CO} \\
(\mathrm{ppm})\end{array}$ & $\begin{array}{c}\mathrm{HCA} \\
\left(\mathrm{mg} / \mathrm{m}^{3}\right)\end{array}$ & $\begin{array}{c}\mathrm{PST} \\
\left(\mathrm{mg} / \mathrm{m}^{3}\right)\end{array}$ \\
\hline $\begin{array}{c}\text { Ovens } \\
\text { F101, }\end{array}$ & 5982 & 110 & 55 & 3.8 & 12 \\
$\begin{array}{c}\text { F102, } \\
\text { F103 }\end{array}$ & & & & & \\
\hline Boiler 1 & 6337 & 119 & 64 & 2.5 & 144 \\
\hline Boiler 2 & 6337 & 119 & 64 & 2.5 & 144 \\
\hline Boiler 3 & 6337 & 119 & 64 & 2.5 & 144 \\
\hline Standard & $<2000^{\mathrm{b}}$ & $460^{\mathrm{b}}$ & - & - & $100^{\mathrm{b}}$ \\
\hline
\end{tabular}

${ }^{a}$ Average Values of pollutants.

${ }^{b}$ Limits that should not be exceeded of pollutants emitted by chimneys of boilers, ovens, incinerators and equipments of electric generation (World Bank Group, 1997).

Table 3. Average polluting load that contribute the valued chimneys, $\mathrm{kg} / \mathrm{h}$.

\begin{tabular}{|c|c|c|c|c|}
\hline Chimneys & $\begin{array}{c}\text { Flow } \\
\left(\mathrm{Nm}^{3} / \mathrm{h}\right)\end{array}$ & $\mathrm{SO}_{2}$ & $\mathrm{NO}_{\mathrm{X}}$ & PST \\
\hline $\begin{array}{c}\text { Ovens } \\
\text { F101, F102, F 103 }\end{array}$ & 25434 & 152 & 2.8 & 3.7 \\
\hline Boiler 1 & 4069 & 25.8 & 0.48 & 0.58 \\
\hline Boiler 2 & 4069 & 25.8 & 0.48 & 0.58 \\
\hline Boiler 3 & 4069 & 25.8 & 0.48 & 0.58 \\
\hline
\end{tabular}

\section{Modeling the Dispersion}

As it is observed in Tab. 4, for the boilers the instantaneous maximum concentration of $\mathrm{SO}_{2}$ finds it at a distance of 210 meters of the source, which means that for concentrations of 20 minutes that area it is contaminated by this pollutant, since the relationship C/CMA is superior to one (NC 39, 1999).

Table 4. Boilers. RC 20 minutes, direction: S-N. Probability of Occurrence: $20 \%$.

\begin{tabular}{|c|c|c|c|c|}
\hline Dist $(\mathrm{m})$ & $\mathrm{C}_{20 \min }$ & $\mathrm{RC}_{20 \min }$ & $\mathrm{C}_{24 \mathrm{~h}}$ & $\mathrm{RC}_{24 \mathrm{~h}}$ \\
\hline 0 & 0 & 0 & 0 & 0 \\
\hline 50 & 0.23971 & 0.47942 & 0.06009 & 1.20173 \\
\hline 100 & 0.65386 & 1.30772 & 0.1639 & 3.27797 \\
\hline 150 & 0.94621 & 1.89242 & 0.23718 & 4.7436 \\
\hline 200 & 1.0355 & 2.071 & 0.25956 & 5.19122 \\
\hline 210 & 1.03697 & 2.07394 & 0.25993 & 5.1986 \\
\hline 250 & 0.99786 & 1.99571 & 0.25013 & 5.00251 \\
\hline
\end{tabular}


In Fig. 1 it is corroborated what had been previously mentioned. Similarly, the daily average concentration ( 24 hours) is a lot superior to that established in the Cuban norm for the ambient air $\left(0.05 \mathrm{mg} / \mathrm{m}^{3}\right)$, reflected in the high ratio of concentration obtained $\left(\mathrm{RC}_{24 \mathrm{~h}}=5.2\right)$.

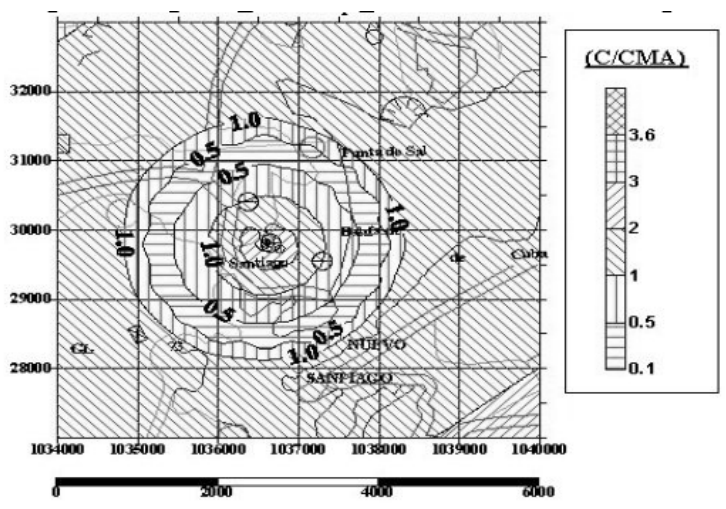

Figure 1. Values of concentration ratio regarding the acceptable one in the boilers.

In Tab. 5 it can be seen that, for the ovens, the instantaneous maximum concentration of $\mathrm{SO}_{2}$ occurs at a distance of 1200 meters of the source, thus for concentrations of 20 minutes and of 24 hours that area is not polluted, since the relationship $\mathrm{C} / \mathrm{CMA}<1$ in both cases, because the height of the chimney, favors the dispersion of the studied pollutant.

In Fig. 2 it is corroborated what was seen before for the emissions of the ovens of the refinery.

In Fig. 3 the impact is shown to take place on the whole area by the boilers and the ovens, and a quite extensive area is observed to be contaminated by $\mathrm{SO}_{2}$, since the $\mathrm{C} / \mathrm{CMA}>1$.

Table 5. Ovens. RC 20 minutes, direction: S-N. Probability of occurrence: $20 \%$.

\begin{tabular}{|c|c|c|c|c|}
\hline Dist (m) & $\mathrm{C}_{20 \min }$ & $\mathrm{RC}_{20 \min }$ & $\mathrm{C}_{24 \mathrm{~h}}$ & $\mathrm{RC}_{24 \mathrm{~h}}$ \\
\hline 0 & 0 & 0 & 0 & 0 \\
\hline 100 & 0.00395 & 0.00789 & 0.00099 & 0.01979 \\
\hline 500 & 0.05917 & 0.11834 & 0.01483 & 0.29662 \\
\hline 1000 & 0.10649 & 0.21297 & 0.02669 & 0.53385 \\
\hline 1200 & 0.10856 & 0.21711 & 0.02721 & 0.54422 \\
\hline 1500 & 0.10236 & 0.20473 & 0.02566 & 0.51317 \\
\hline 2000 & 0.09069 & 0.18137 & 0.02273 & 0.45463 \\
\hline 2500 & 0.07909 & 0.15818 & 0.01982 & 0.39649 \\
\hline
\end{tabular}

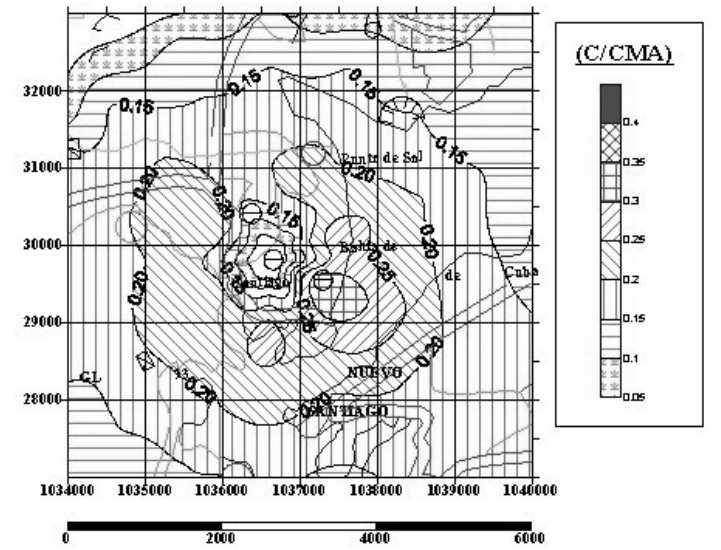

Figure 2. Values of concentration ratio regarding the acceptable one in the ovens.

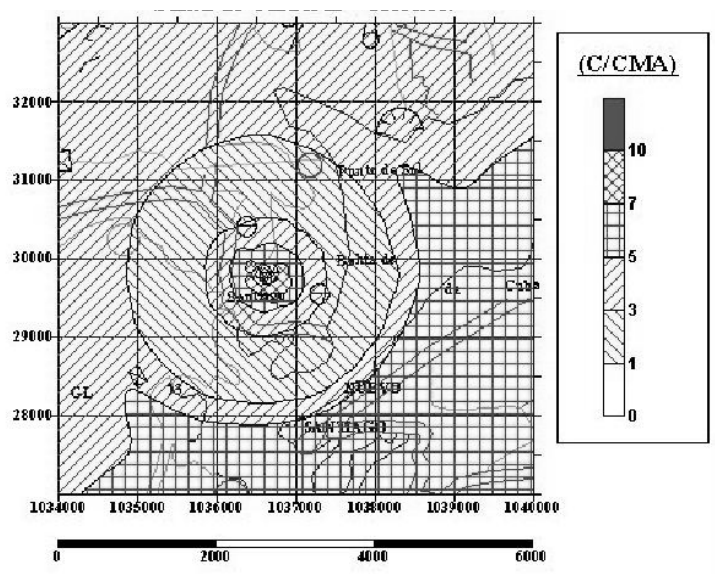

Figure 3. Values of RC 20 minutes regarding the acceptable one, ovens + boilers.

\section{Statistical analysis}

The multivariate statistical analysis using the method of union of the centroide of group of couples weighed by the Euclidean distances shows in the tree diagram (Fig. 4), two very defined groups of variables, one of those reflects the relationship of the CO with NOx and TSP, associated to the conditions of operation of ovens and boilers, and the other one relates to the $\mathrm{CO}$ with the aromatic hydrocarbons.

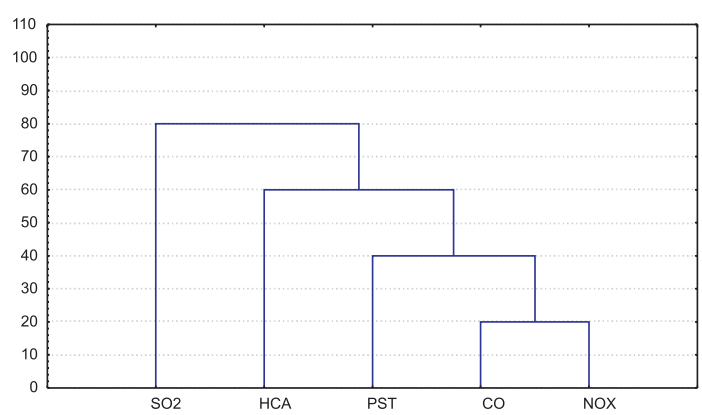

Figure 4. Diagram of tree of the variables. 


\section{TECNOLOGIA/TECHNOLOGY}

From the regression analysis step by step, highly significant correlation coefficients were obtained for $\alpha=0.05$ of the levels of concentration of the NOx and the aromatic hydrocarbons with the $\mathrm{CO}$ (Tab. 6).

Table 6. Obtained correlation coefficients.

\begin{tabular}{|c|c|c|c|}
\hline & $\mathrm{NO}_{\mathrm{x}}$ & $\mathrm{HCA}$ & TSP \\
\hline $\mathrm{CO}$ & 0.999 & 0.961 & 0.810 \\
\hline
\end{tabular}

\section{CONCLUSIONS}

The combustion processes in the ovens and boilers of the Refinery reflect a faulty combustion, given the found emissions of particles. The combined emissions of the ovens and boilers exercise negative impact or pressure on the atmospheric ambient in the area.

\section{REFERENCES}

Álvarez, O., 1994, Diagnóstico y pronóstico de la contaminación por $\mathrm{SO}_{2}$ y $\mathrm{H}_{2} \mathrm{~S}$ en Moa. Modelación con consideraciones de terreno plano. Tesis en opción al Grado Científico de Dr. en Ciencias Geográficas, La Habana. (in Spanish)

ARPEL. GAA 7, 1992, Reducción y control de emisiones gaseosas de refinerías de petróleo. (in Spanish)

ARPEL. GAA 29, 1999, Optimización de la combustión en calderas y hornos. (in Spanish)

ARPEL. GAA 22, 1998, Metodologías de inventarios de emisiones atmosféricas en la industria petrolera. (in Spanish)

ARPEL, 1997, Environmental Monitoring Procedures. Komex Int. Ltd., Calgary.

Brieda, F et al., 1986, Methods of sampling and analysis for sulfur dioxide, NOx and particulate matter in the exhaust gases of large combustion plants. Report EUR-10645-EN 156 pp.

Calvert, S., Englund, H. M., 1984, Handbook of air pollution technology. John Wiley and Sons, N.Y.

Cheremisinoff, P.N., Morresi, A. C., 1978, Air Pollution Sampling and Analysis Deskbook. Ann Arbor Science, Michigan.

INFOPET, 1999, Mapas digitales escala 1:250000. Hojas cartográficas, Varadero, Península de Hicacos y Cárdenas. La Habana. (in Spanish)

ISO 10396, 1993, Emisiones de fuentes estacionarias. Muestreo para la determinación automática de concentraciones de gases. (in Spanish)

ISO 9096, 1992, Concentración y flujo másico de partículas en emisiones. Método gravimétrico. (in Spanish)

Jahnke, J.A., 1993, Continuous emissions monitoring. Van Nostrand Reinhold, N.Y.

Kiely, G., 1997, Environmental Engineering. Mc Graw Hill International Ed., U.K.

López, C., 1995, La 1luvia ácida, un problema ambiental en Cuba?. Boletín CIMAA 1: 2-4. (in Spanish)

López, C., 1984, Factores meteorológicos de la contaminación regional del aire en Cuba. Tesis para el grado de Doctor en Ciencias FísicoMatemáticas, INSMET, La Habana. (in Spanish)

NC 39, 1999. Calidad del aire. Requisitos higiénico - sanitarios. La Habana. (in Spanish)

Novello, D.P., 1995, Clean Air Operating Permits: A practical guide. Air \& Waste Management Assoc. Pittsburg.

Porteous, A., 1996, Dictionary of Environmental Science and Technology. $2^{\text {nd }}$ ed. John Wiley \& Sons. Toronto.

Rudolph, R. et al., 1997, Métodos de monitoreo de la calidad del aire. ARPEL, Calgary. (in Spanish)

Slater, D., 1996, Meeting the challenges of Integrated Pollution Control. Industry and Environment, Vol. 19, No. 1, pp. 19-22.

UNEP, 1992, Chemical Pollution: A Global Overview. IRPTC. Geneve.

Wagner, T., 1996, Contaminación, causas y efectos. 423 p. Ed. Gernika, México D.F. (in Spanish)

White, J.R., 1995, Technologies for Enhanced Monitoring. Pollution Engineering, Vol. 27, No. 6, pp. 46-50.

World Bank Group, 1997, Pollution Prevention and Abatement Handbook. Annual Meeting Ed.

Yoest, H., Fitzgerald, R. W., 1996, Stationary Source Testing: The Fundamentals. Chemical Eng. Progress, Vol. 92, No. 2, pp. 36 - 41. 